\title{
The vibration of the friction pads of disc brake in the aspect of changing the coefficient of friction
}

\begin{abstract}
Attempt to raise train speed involves application of greater braking power i.e. braking systems rapidly absorbing and dispersing stored heat energy. Work instability arises from the occurrence of vibrations on friction element, which affects the lower efficiency of the braking process. In practice, this means that, during braking the vehicles currently alternative at a time of friction resistance may cause uneven braking process. The effects of these changes can manifest in the form of vibrations the high amplitude of the input.
\end{abstract}

The purpose of this article is to present the relationship between the changes in instantaneous coefficient of friction of the disk brake and the changes in instantaneous accelerations of the vibrations of the friction pad during braking.

\section{Wpływ drgań okładzin ciernych hamulca tarczowego na zmiany współczynnika tarcia}

\begin{abstract}
W pojazdach szynowych ze względu na coraz to większe prędkości jazdy prowadzi się prace nad udoskonalaniem układów hamulcowych tak, aby zatrzymanie pojazdu odbyto się na możliwie najkrótszej drodze hamowania. Niestabilność pracy wynika między innymi z występowania drgań na styku elementów ciernych, co wptywa na obniżenie sprawności procesu hamowania. W praktyce oznacza to, że podczas hamowania pojazdów wystęujacy zmienny $w$ czasie opór tarcia może być powodem nierównomiernego przebiegu procesu hamowania. Skutki tych zmian moga objawić się w postaci drgań samowzbudnych.

Celem artykulu jest przedstawienie zwiqzku zmian chwilowego wspótczynnika tarcia hamulca tarczowego ze zmianami chwilowych przyspieszeń drgań okładziny ciernej w czasie hamowania.
\end{abstract}

\section{WPROWADZENIE}

W wielu pojazdach szynowych, hamulcem ciernym jest hamulec tarczowy, co wynika $\mathrm{z}$ uzyskiwanych prędkości jazdy oraz mocy hamowania. Hamulec tarczowy, mimo że jest podstawowym pneumatycznym hamulcem ciernym EP, w niektórych pojazdach jak np. w elektrycznych zespołach trakcyjnych współpracuje $\mathrm{z}$ hamulcem elektrodynamicznym ED. Istotną zaleta hamulca tarczowego $\mathrm{w}$ porównaniu $\mathrm{z}$ hamulcem klockowym jest stała wartość średniego współczynnika tarcia wynosząca 0,35 , niezależnie od prędkości początku hamowania [4]. Jednak na przebieg chwilowego, a w konsekwencji średniego współczynnika tarcia, wpływa współpraca okładziny ciernej z tarczą hamulcową w czasie hamowania. Niestabilność pracy hamulca wynika zarówno ze zjawisk cieplnych [1] jak również z drgań okładziny, i skutkuje obniżeniem sprawności całego procesu hamowania $[8,9]$. To z kolei ogranicza trwałość elementów układu hamulcowego oraz wpływa na przenoszenie drgań na pojazd, co obniża komfort podróżowania pasażerów. Konsekwencją drgań układu hamulcowego w połączeniu z

\section{INTRODUCTION}

Taking into account the travelling speed and, in consequence, the required braking power, the disk brake is used as a friction brake of many rail vehicles. The disk brake, despite being a service electro-pneumatic (EP) friction brake, is associated with the electrodynamic (ED) one in some vehicles, as e.g. in the electric multiple units. A major advantage of the disk brake as compared to the block one consists in constant value of the mean coefficient of friction, equal to 0.35 , irrespective of initial speed at the beginning of braking [4]. Nevertheless, the progress of current coefficient of friction and, consequently, of the mean coefficient of friction, is affected by mating of the friction pad with the brake disk during braking. Instability of the brake operation is a result both of the thermal phenomena [1] and the pad vibration. Therefore, efficiency of braking is worsened [8,9]. This, in turn, reduces lifespan of the braking system parts. The vibration is transferred to the vehicle as a whole, thereby impairing the passenger comfort. Apart from the noise propagation the braking system vibration is 
propagacją dźwięku jest niestabilna praca układu hamulcowego objawiająca się zmiennym przebiegiem chwilowego współczynnika tarcia.

\section{OBIEKT I METODYKA BADAŃ}

Badania przeprowadzono na tarczy hamulcowej o wymiarach $610 \times 110 \mathrm{z}$ wentylującymi łopatkami wykonanej z żeliwa szarego (rys. 1a)) oraz na okładzinach hamulcowych typu 200 FR20H.2 firmy Fenoplast (rys. 1b). Okładziny, zgodnie z procedurą producenta, są wykonane z żywicy termoutwardzalnej, elastomeru syntetycznego, włókna metalowego i organicznego oraz modyfikatorów tarcia. Do badań stanowiskowych zastosowano jedną parę okładzin o grubości $\mathrm{g}_{3}=15 \mathrm{~mm}$. Na jeden komplet okładzin ciernych przypadają 4 sztuki zakładane po dwie na obsadę prawą i lewą mechanizmu dźwigniowego hamulca.

Badania o charakterze cierno-wibroakustycznym zostały przeprowadzone jednocześnie na stanowisku hamulcowym bezwładnościowym, przedstawionym na rysunku 2. Na stanowisku jest możliwe wykonanie badań kolejowego hamulca klockowego oraz hamulca tarczowego, odzwierciedlających rzeczywiste warunki, jakie występują podczas hamowania wagonu.

a)

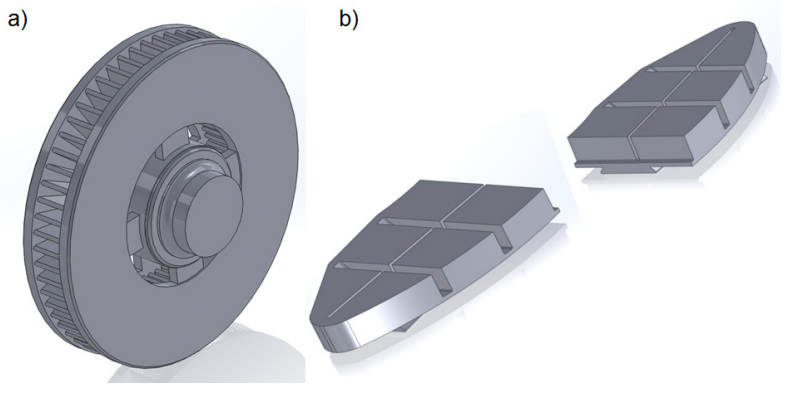

Rys. 1. Obiekt badań: a) tarcza hamulcowa typu $610 \times 110$, b) okładzina cierna typu 200P i 200L

Fig. 1. The object of the tests: a) the brake disc of $610 \times 110$ type, b) the friction pads of $200 \mathrm{P}$ and $200 \mathrm{~L}$ types conducive to unstable operation of the braking system manifesting itself by variations of instantaneous coefficient of friction.

\section{THE OBJECT AND METHODS OF THE RESEARCH}

The tests have been carried out with the brake disk of $610 \times 110$ dimensions, provided with the vent blades made of grey cast iron (Fig. 1a) and brake pads of 200 FR20H.2 type, from Fenoplast Company (Fig. 1b). According to manufacturer's procedures the pads are made of thermosetting resins, synthetic elastomer, metallic and organic fibre, and friction modifiers. For purposes of the bench tests a single pair of friction pads was used, having the thickness $\mathrm{g}_{3}=15 \mathrm{~mm}$. One set of the friction pads includes four pieces - two pads mounted in each of the brakeholders, i.e. in left-hand and right-hand holders of the brake mechanism.

The tests, with consideration of the friction and vibroacoustic phenomena, have been carried out simultaneously on the brake - inertia test bench shown in Fig. 2. The bench allows to conduct the test of the railway block brake and disc brake, with consideration of current conditions arising during railway carriage braking.

For the test purposes the $\mathrm{C}$ research program formulated in the UIC 541-3 chart was used. According to the program the brake trials until stoppage have been carried out, using the disk surface pressure of $\mathrm{N}=28 \mathrm{kN}$ and $44 \mathrm{kN}$. The braking mass per one disk was assumed to $\mathrm{M}=4.4 \mathrm{t}$. The vibration transmitters have been fixed to the brakeholders with the help of a mounting plat [2] (shown in Fig. 3).

The vibration signal have been acquired by a measurement set including two B\&K piezo-electric vibration transmitters of 4504A type, the $\mathrm{B} \& \mathrm{~K}$ measurement cassette of 3050-A-060 type and the PULSE 16 system software.

b)

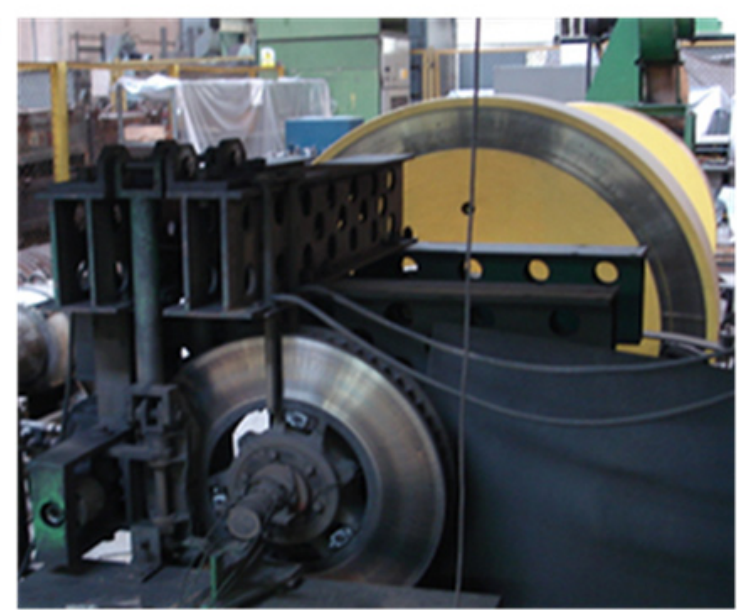

a)

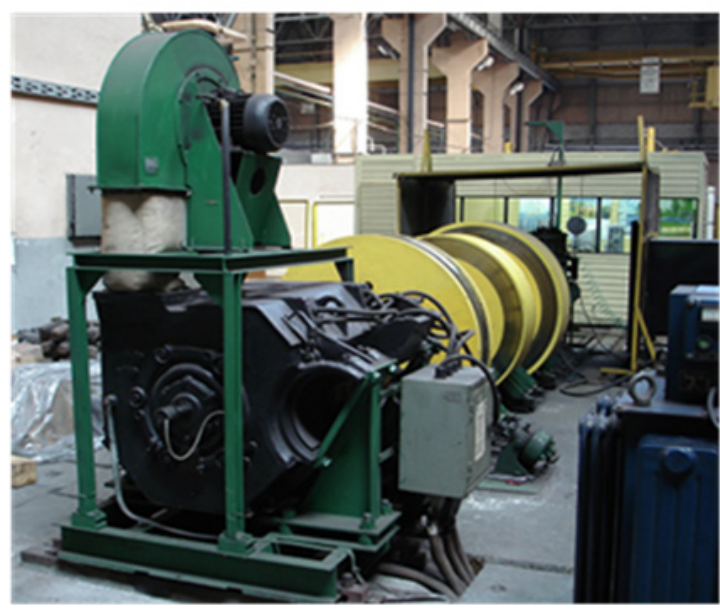

Rys. 2. Stanowisko hamulcowe do badań kolejowych układów hamulcowych (klockowych i tarczowych) a) widok części napędowej stanowiska, b) widok części pomiarowej stanowiska

Fig. 2. The brake stand designed for testing the brake systems (of block and disc types), a) view of the stand drive part, b) view of the measurement system of the stand 
Do badań wykorzystano program badawczy C zawarty w karcie UIC 541-3. Dla wspomnianego programu przeprowadzono hamowania zatrzymujące z prędkości $\mathrm{v}=160 \mathrm{~km} / \mathrm{h}$, nacisk okładziny na tarczę $\mathrm{N}=28 \mathrm{i} 44 \mathrm{kN}$. Masa do wyhamowania przypadająca na jedną tarczę wyniosła w czasie badań $\mathrm{M}=4,4 \mathrm{t}$. Na obsadach hamulcowych zamocowano przetwornik drgań (co przedstawia rysunek 3) za pośrednictwem płytki mocującej [2].

Do akwizycji sygnałów drgań zastosowano zestaw pomiarowy składający się z piezoelektrycznych przetworników drgań B\&K typ 4504A (2szt.), kasety pomiarowej typu B\&K 3050-A-060 oraz z oprogramowania systemu PULSE 16.

Przy wyborze miejsca pomiarowego przyjęto zasadę, że przetworniki powinny znajdować się najbliżej miejsca generującego sygnał związany z pracą pary ciernej oraz $\mathrm{w}$ miejscu łatwo dostępnym $\mathrm{w}$ celu przeprowadzenia pomiaru.

W dalszej części badań stanowiskowych z przetwornikami trójosiowymi i wyborze jednego referencyjnego kierunku drgań, badania przeprowadzono na jednym kanale dla obu przetworników drgań zamocowanych do obsad hamulcowych. Podczas badań rejestrowano sygnały przyspieszeń drgań $\mathrm{w}$ jednym kierunku tj. prostopadłych do powierzchni ciernej tarczy hamulcowej [2]. Tor pomiarowy przedstawiono na rysunku 4.

Przetworniki drgań typu 4504 firmy Brüel\&Kjær wybrano na podstawie wytycznych zawartych $\mathrm{w}$ pracy [3], liniowe pasmo przenoszenia przetworników wyniosło $18 \mathrm{kHz}$. Częstotliwość próbkowania ustawiono na $131 \mathrm{kHz}$. Oznacza to, że pasmo poddane analizie zgodnie z zależnością Nyquista wyniosło $65 \mathrm{kHz}$.

\section{WYNIKI BADAŃ}

$\mathrm{Na}$ rysunku 5 przedstawiono przebieg chwilowych przyspieszeń drgań obsady hamulcowej z okładzinami ciernymi w czasie hamowania zatrzymującego z prędkości $\mathrm{v}=160 \mathrm{~km} / \mathrm{h}$. Na wspólnym rysunku zestawiono dwa hamowania przeprowadzone w tych samych warunkach oraz przy tych samych nastawach jak nacisk
The choice of measurement points has been made in accordance with the principle that the transmitters should be located in the vicinity of the signal generation place, i.e. near the friction pair position, and in the location easily accessible for the measurement purpose. a)

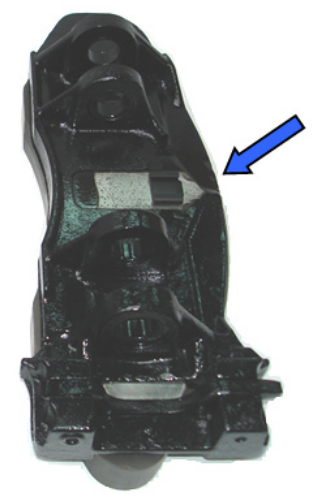

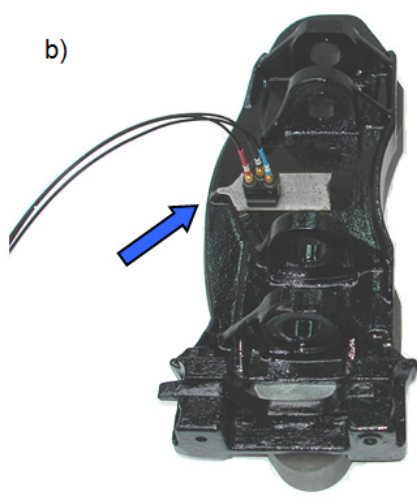

Rys. 3. Obsady okładzin ciernych do badań cierno-wibroakustycznych a) widok obsady z wyfrezowanym gniazdem pod przetwornik drgań, b) widok obsady z zamocowanym przetwornikiem drgań

Fig. 3. Friction pad holders designed for the friction-vibroacoustic tests, a) view of the holder with a socket milled for the vibration transmitter; b) view of the holder with fixed vibration transmitter

During further course of the bench tests with the use of three-axis transmitters and chosen one reference direction of the vibration, the trials have been conducted with the use of single channel for both transmitters fixed to the brakeholders. The vibration acceleration signals have been recorded in one distinguished direction, i.e. perpendicularly to the brake disk surface [2]. The measurement chain is shown in Figure 4.

The vibration transmitters from Brüel\&Kjær of 4504 type are chosen based on the guidelines presented in [3]. Linear bandwidth of the transmitters is equal to $18 \mathrm{kHz}$. Sampling frequency was adjusted to $131 \mathrm{kHz}$. It means that, according to the Nyquist rule, the analyzed band was equal to $65 \mathrm{kHz}$.

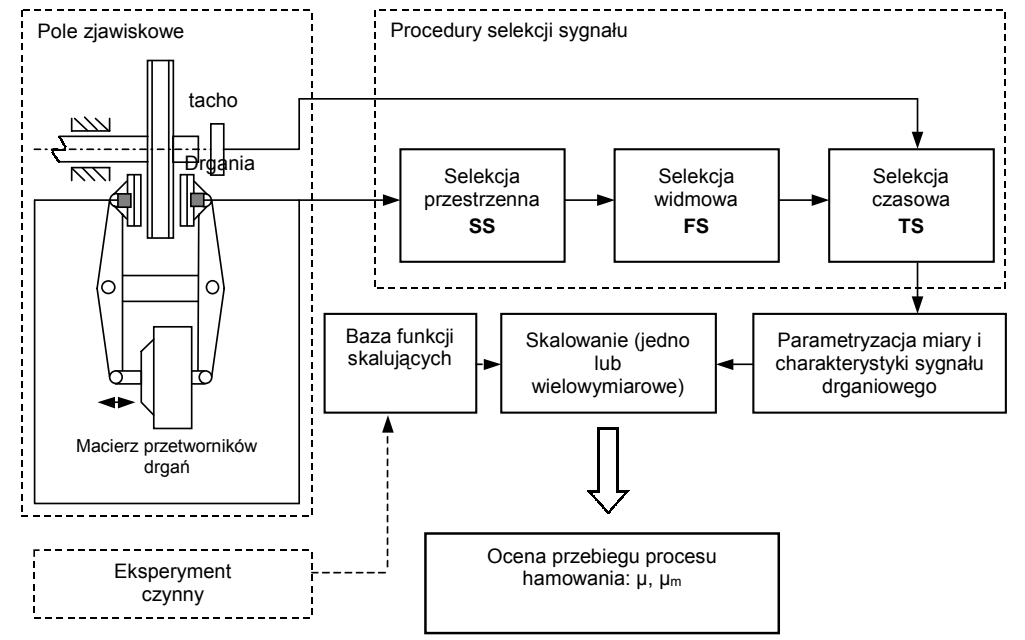

Rys.4. Schemat toru pomiarowego przyspieszeń drgań generowanych przez obsadę hamulcową z okładzinami w czasie hamowania

Fig. 4. Scheme of the measurement chain of the vibration accelerations generated by the brakeholder with the pads during the braking process 
okładziny do tarczy, masa do wyhamowania oraz temperatura początkowa tarczy przed hamowaniem. W przypadku drugiego hamowania zaobserwowano $\mathrm{w}$ ostatniej fazie hamowania drgania samowzbudne o charakterze rezonansowym.

Jednocześnie na stanowisku hamulcowym rejestrowano parametry cierne jak czas hamowania, droga hamowania oraz współczynnik tarcia. Na rysunku 6 przedstawiono przebieg prędkości pojazdu $\mathrm{w}$ funkcji czasu hamowania. $\mathrm{W}$ innej próbie hamowania $\mathrm{z}$ prędkości $\mathrm{v}=160 \mathrm{~km} / \mathrm{h}$ z naciskiem $\mathrm{N}=44 \mathrm{kN}$ i masie do wyhamowania $M=4,4 t$ drgania rezonansowe przyczyniły się do skrócenia czasu hamowania. $W$ tych dwóch przypadkach hamowania uzyskano następujące drogi hamowania: dla pierwszej próby, gdzie nie wystapiły drgania rezonansowe $S_{1}=665,6 \mathrm{~m}$, natomiast $\mathrm{w}$ kolejnej, z widocznymi drganiami rezonansowymi w ostatniej fazie hamowania $S_{2}=657,8 \mathrm{~m}$.
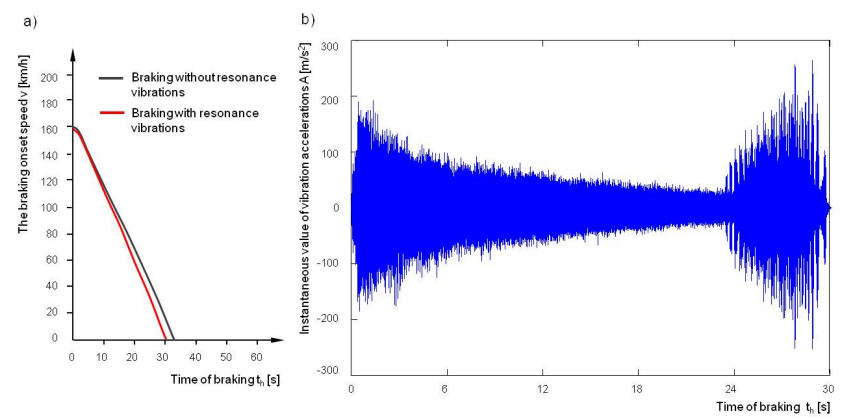

Rys. 6. Wyniki badań $\mathrm{z}$ hamowania $\mathrm{z}$ prędkości $\mathrm{v}=160 \mathrm{~km} / \mathrm{h}$ przy $\mathrm{N}=44 \mathrm{kN}$ i $\mathrm{M}=4,4$ a) przebieg zmiany prędkości hamowania $\mathrm{W}$ funkcji czasu hamowania, b) przebieg chwilowych przyspieszeń drgań w czasie hamowania, przebieg czarny - pierwsze hamowanie, przebieg czerwony - drugie hamowanie z widocznymi drganiami samowzbudnymi o charakterze rezonansowym

Fig. 6. Results of the braking tests for the onset speed $v=160 \mathrm{~km} / \mathrm{h}$, the pressure equal to $\mathrm{N}=44 \mathrm{kN}$ and mass $\mathrm{M}=4.4 \mathrm{t}$; a) relationship between the vehicle speed and braking time; b) progress of instantaneous vibration accelerations during braking - the black graph the first braking trial, the red graph - the second braking trial with self-oscillation of resonance nature noticeable in the diagram

Pomiar współczynnika tarcia jest stosowany do oceny skuteczności hamowania i odbywa się w warunkach badań stanowiskowych. Podczas badań na stanowisku bezwładnościowym [5,6] jest określany chwilowy współczynnik tarcia $\mu_{a}$, w każdej chwili hamowania zgodnie z zależnością (1.1):

$$
\mu_{a}=\frac{F_{t}}{F_{b}}
$$

gdzie: $F_{t}$ - chwilowa siła styczna odniesiona do promienia hamowania $r$,

$F_{b}$ - całkowita chwilowa siła nacisku na tarczę hamulcową.

Następnie obliczany był średni współczynnik tarcia $\mu_{m}$, wyznaczany z całki oznaczonej chwilowego

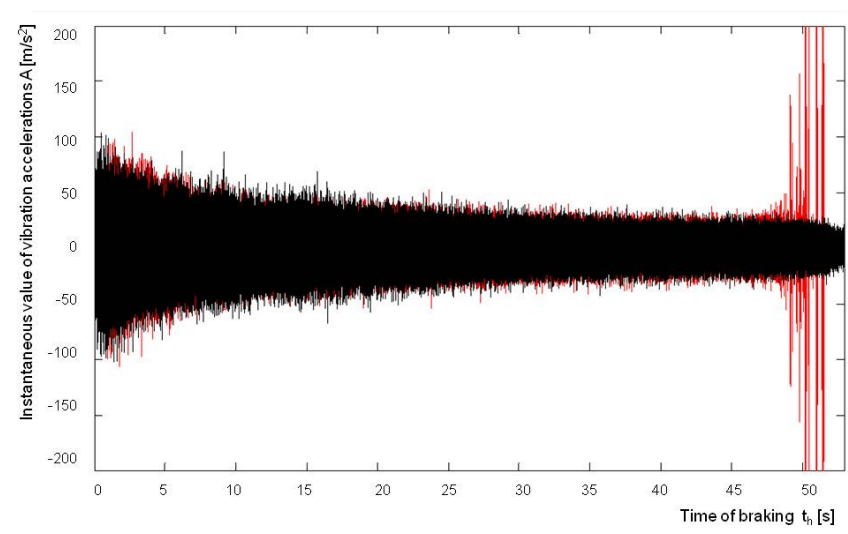

Rys. 5. Przebieg chwilowych przyspieszeń drgań obsady z okładzinami ciernymi w czasie hamowania z prędkości $\mathrm{v}=160 \mathrm{~km} / \mathrm{h}$ przy $\mathrm{N}=28 \mathrm{kN}$ i $\mathrm{M}=4,4 \mathrm{t}$, przebieg czarny - pierwsze hamowanie, przebieg czerwony - drugie hamowanie $\mathrm{z}$ widocznymi drganiami samowzbudnymi o charakterze rezonansowym

Fig. 5. Progress of instantaneous vibration accelerations of the brakeholder provided with friction pads during braking from the speed $\mathrm{v}=160 \mathrm{~km} / \mathrm{h}$, with $\mathrm{N}=28 \mathrm{kN}$ and $\mathrm{M}=4.4 \mathrm{t}$; the black graph the first braking trial, the red graph - the second braking trial with self-oscillation of resonance nature noticeable in the diagram

\section{RESULTS OF THE TESTS}

Figure 5 presents the progress of instantaneous vibration accelerations of the brakeholder with the friction pads during the braking trial from the speed $\mathrm{v}=160 \mathrm{~km} / \mathrm{h}$ to stoppage. The common graph includes two braking trials carried out under equal conditions and the same adjustment, i.e. the pad pressure against the disk, the braked mass, and initial disk temperature before the braking. In case of the second braking trial the self-oscillation of resonance nature is observed at final stage of braking.

Furthermore, the other friction parameters, namely the braking time, stopping distance, and coefficient of friction, have been also recorded in the brake test bend. Figure 6 shows the relationship between the vehicle speed and braking time. In case of another braking trial with the onset speed $v=160 \mathrm{~km} / \mathrm{h}$, the pressure equal to $\mathrm{N}=44 \mathrm{kN}$ and braked mass $\mathrm{M}=4.4 \mathrm{t}$ the resonance vibration contributed to reduction of the braking time. The following stoppage distance values have been obtained: in case of the first trial without the resonance vibration $S_{1}=665.6 \mathrm{~m}$, while for the other one, with visible resonance vibration at the last stage of braking $S_{2}=657.8 \mathrm{~m}$.

The coefficient of friction is measured with a view to assess the braking efficiency, the measurement is carried out in the test bench. In any moment of braking the instantaneous coefficient of friction $\mu_{a}$ is determined at the inertia test bench $[5,6]$, according to the formula (1.1):

$$
\mu_{a}=\frac{F_{t}}{F_{b}}
$$

where: $F_{t}-$ instantaneous transverse force converted to the braking radius r; 
współczynnika tarcia po drodze hamowania $s_{2}$ zgodnie $\mathrm{z}$ równaniem (1.2) [5]:

$$
\mu_{m}=\frac{1}{s_{2}} \int_{0}^{s_{2}} \mu_{a} d s
$$

gdzie: $s_{2}-$ droga hamowania w metrach.

Na podstawie zależności (1.1) oraz (1.2) wyznaczane są charakterystyki $\mu_{a}=f(t)$ oraz $\mu_{m}=f(v)$. Podczas badań stanowiskowych hamulca kolejowego rejestruje się przebieg chwilowego współczynnika tarcia w czasie hamowania od zadanej prędkości hamowania aż do zatrzymania. Na tej podstawie określa się chwilę osiągnięcia wartości maksymalnej oraz minimalnej chwilowego współczynnika tarcia. Przebiegi otrzymane z zależności (1.2) stanowią końcowe zestawienia sprawdzające zachowanie się współczynnika tarcia w całym zakresie prędkości hamowania danego pojazdu.
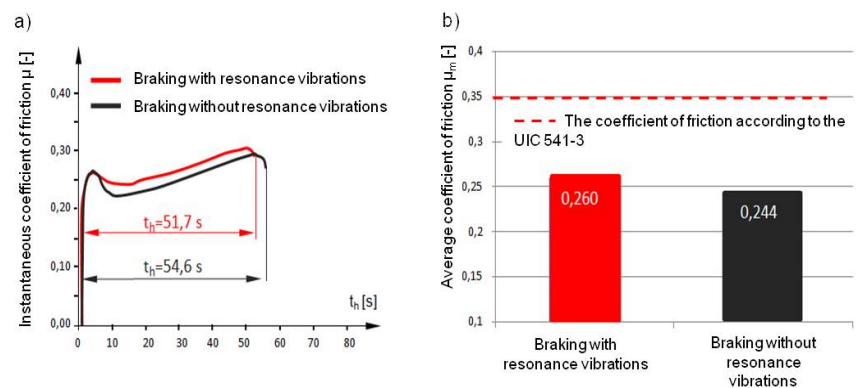

Rys. 7. Przebieg współczynnika tarcia a) chwilowego, b) średniego w czasie hamowania $\mathrm{z}$ prędkości $\mathrm{v}=160 \mathrm{~km} / \mathrm{h}, \mathrm{N}=28 \mathrm{kN}$ i $\mathrm{M}=4,4$, przebieg czarny - pierwsze hamowanie, przebieg czerwony drugie hamowanie $\mathrm{z}$ widocznymi drganiami samowzbudnymi o charakterze rezonansowym

Fig. 7. Pattern of the coefficient of friction a) instantaneous one; b) mean one, for braking from $v=160 \mathrm{~km} / \mathrm{h}, \mathrm{N}=28 \mathrm{kN}$ and $\mathrm{M}=4.4 \mathrm{t}$; the black graph - the first braking trial, the red graph - the second braking trial with visible self-oscillation of resonance nature

Ocenę procesu hamowania jak i stanu danej pary ciernej [7] określa się przez naniesienie tolerancji chwilowego i średniego współczynnika tarcia na otrzymane i wyliczone wartości współczynników zgodnie z Kartą UIC 541-3. Na rysunku 7 przedstawiono przebieg zarówno chwilowego jak i średniego współczynnika tarcia w czasie hamowania $\mathrm{z}$ prędkości $\mathrm{v}=160 \mathrm{~km} / \mathrm{h}$. Porównując wyniki badań ciernych $\mathrm{z}$ przebiegiem chwilowych przyspieszeń drgań obsady hamulcowej z okładzinami (rys. 5) zauważa się, że proces hamowania $\mathrm{z}$ drganiami o charakterze rezonansowym charakteryzuje się wyższym współczynnikiem tarcia co w konsekwencji przekłada się na krótszy czas hamowania. Badania na parą cierną złożoną $\mathrm{z}$ organicznej okładziny ciernej i żeliwnej tarczy hamulcowej wykazały, że podczas hamowania tylko okładziny zużyte do grubości $15 \mathrm{~mm}$ wykazywały tendencję do drgań o charakterze rezonansowym, natomiast $\mathrm{w}$ przypadku okładzin nowych takiej tendencji nie obserwowano.

\section{$F_{b} \quad-$ total instantaneous force exerting pressure on the brake disk.}

Thereafter, an average coefficient of friction $\mu_{m}$ was calculated as a definite integral of the instantaneous coefficient of friction with respect to the braking distance $s_{2}$, according to the equation (1.2) [5]:

$$
\mu_{m}=\frac{1}{s_{2}} \int_{0}^{s_{2}} \mu_{a} d s
$$

where: $\quad s_{2} \quad-\quad$ the braking distance in meters.

Based on the equations (1.1) and (1.2) the characteristics $\mu_{a}=f(t)$ and $\mu_{m}=f(v)$ are determined.

During the bench tests of the railway carriage brake the pattern of the instantaneous coefficient of friction is recorded during the braking process, starting from the assumed speed until stoppage. This provides a basis for determining the moment when maximum and minimum instantaneous coefficient of friction is reached. The patterns obtained from the formula (1.2) are final specifications illustrating the behaviour of the coefficient of friction in the whole speed range of braking.

The braking process and the condition of the friction pair [7] is assessed by plotting the tolerances of the instantaneous and mean coefficients of friction on the values of the coefficients obtained and calculated in accordance with the UIC 541-3 chart. Figure 7 shows the patterns of both instantaneous and mean coefficients of friction obtained during braking starting from the speed $v=160 \mathrm{~km} / \mathrm{h}$. It may be noticed, based on comparison of the results of the friction tests to the patterns of instantaneous vibration accelerations of the brakeholder with the pads (Fig. 5), that the braking process accompanied by the vibration of resonance nature leads to higher value of the coefficient of friction and, in consequence, to reduced braking time. The tests conducted for the friction pair composed of organic friction pad and cast iron brake disk demonstrated that only the pad worn until the thickness reduced to $15 \mathrm{~mm}$ showed a trend to exciting the resonance vibration, while in case of new pads such a trend has not been observed.

\section{SUMMARY}

The friction and vibroacoustic tests carried out at the brake bench have shown that the braking processes are not repetitive. Taking into account the friction parameters the braking process (ensuring equal adjustment of the parameters, i.e. speed, the pad pressure, braked mass and temperature of the brake disk before new braking trial) may be evaluated based on mean values of the coefficient of friction or on observation of instantaneous patterns of the coefficient. However, taking into account broadly understood diagnostic and vibroacoustic parameters, the braking 


\section{PODSUMOWANIE}

Przeprowadzone jednoczesne badania o charakterze ciernym i wibroakustycznym na stanowisku hamulcowym wykazały, że dla konkretnego przypadku hamowania proces hamowania nie jest powtarzalny. W przypadku parametrów ciernych proces hamowania (przy tych samych nastawach jak prędkość, nacisk okładziny, masa do wyhamowania oraz temperatura tarczy hamulcowej przed kolejną próbą hamulcową) można ocenić poprzez uzyskiwane średnie wartości współczynnika tarcia lub obserwując chwilowe przebiegi współczynnika tarcia. Natomiast $\mathrm{w}$ przypadku szeroko rozumianych parametrów diagnostycznych wibroakustycznych, proces hamowania można ocenić (porównać) rejestrując chwilowe przyspieszenia drgań obsady z okładzinami ciernymi. W tym przypadku, co potwierdziły przeprowadzone badania, można stwierdzić, że istnieje związek zmian chwilowego współczynnika tarcia $\mathrm{z}$ jednoczesnymi zmianami przebiegów chwilowych przyspieszeń drgań obsady z okładzinami ciernymi. Dla konkretnego przypadku hamowania wzrost chwilowych przyspieszeń drgań w czasie hamowania $\mathrm{z}$ jednoczesnymi drganiami samowzbudnymi rezonansowymi w ostatniej fazie hamowania przyczynił się do wzrostu chwilowego współczynnika tarcia w porównaniu do takiej samej próby hamowania z niższą wartością chwilowych przyspieszeń drgań i bez drgań o charakterze rezonansowym. Aby jednoznacznie stwierdzić związek wzrostu przyspieszeń drgań elementów ciernych $\mathrm{z}$ przebiegiem chwilowego współczynnika tarcia (szczególnie w ostatniej fazie hamowania) konieczne jest przeprowadzenie dalszych badań $\mathrm{z}$ uwzględnieniem innych prędkości początku hamowania, różnych nacisków okładzin do tarczy oraz różnych mas do wyhamowania. Wskazane jest ponadto przeprowadzenie testów impulsowych pozwalających na określenie częstotliwości drgań własnych elementów układu hamulcowego.

Ponadto przeprowadzone badania dowodzą o niestabilności przebiegu współczynnika tarcia mimo tych samych nastaw, gdzie oprócz parametrów związanych z prędkością, naciskiem, masą do wyhamowania oraz temperaturą tarczy hamulcowej, inne parametry mogą mieć wpływ na zmienny przebieg zarówno chwilowego jak i średniego współczynnika tarcia. Do tych parametrów można zaliczyć temperaturę okładziny ciernej oraz stan powierzchni styku okładziny z tarczą hamulcową poprzez występowanie tzw. nalewów, które cyklicznie powstają oraz są zrywane w kolejnych hamowania.

W trakcie hamowania produkty zużycia okładziny i tarczy łączą się i przywierają do okładziny, tworząc dodatkową trzecią warstwę na okładzinie. W dalszych badaniach należy określić wpływ tej warstwy nadbudowanej na okładzinie na przebieg chwilowego współczynnika tarcia. process may be assessed by registering the instantaneous accelerations of vibrating brakeholder provided with friction pads. In this case instantaneous variations of coefficient of friction are related to simultaneous variations of the patterns of instantaneous accelerations of vibrating brakeholder with the friction pads, which was confirmed by the tests. In the specific braking case the growth of instantaneous vibration accelerations while braking, accompanied at its last stage by resonance self-oscillation, causes the increase in instantaneous coefficient of friction as compared to the same braking trial distinguished by lower values of the instantaneous vibration accelerations without the resonance vibration. In order to explicitly verify the relationship between the growth of vibration accelerations of the friction elements and the pattern of instantaneous coefficient of friction (particularly at the last braking stage) further research is necessary for other braking onset speeds, varying values of the pad pressure exerted on the disk and changing mass to be braked. Moreover, the pulse tests would be recommended, with a view to determine free vibration frequencies of the brake system elements. Furthermore, the tests carried out reveal instability of the pattern of coefficient of friction, in spite of equal setting of the system. Apart from the parameters related to the speed, pressure, the braked mass, and brake disk temperature, another parameters may affect the pattern of instantaneous and mean coefficient of friction. There are among them the temperature of the friction pad and the condition of the pad/brake disk contact surface, where so-called lugs may occur that are ripped in further braking events.

The wear and tear products of the pads and disk bind to the pad surface, thus making a third additional layer. Further research shall be an attempt to determine the effect of the third layer on the pattern of instantaneous coefficient of friction.

Projekt jest finansowany ze środków Narodowego Centrum Badań i Rozwoju, program LIDER V, umowa Nr LIDER/022/359/L-5/13/NCBR/2014

The project is financed by The National Centre for Research and Development, the LIDER V Program, Contract No L

\section{LITERATURA}

[1] Belhocine A., Bouchetara M., Thermomechanical modelling of dry contacts in automotive disc brake. International Journal of Thermal Sciences 60 (2012) 161-170.

[2] Brüel\&Kjor, Piezoelectric Accelerometer Miniature Triaxial Delta Tron Accelerometer - Type 4504A, oferta firmy Brüel \& Kjar, s. 2.

[3] Brüel\&Kjaer, Measuring Vibration. Revision September 1982, s. 16. 
[4] Kaluba M., Zużycie okładzin ciernych hamulca tarczowego pojazdów szynowych, Pojazdy Szynowe 1999 $n r$ 4, s. 24-29.

[5] Karta UIC 541-3, Hamulec-Hamulec tarczowy i jego zastosowanie. Warunki dopuszczenia okładzin hamulcowych, Wyd. 6, listopad 2006, s. 23.

[6] Piechowiak T., Hamulce pojazdów szynowych, Wydawnictwo Politechniki Poznańskiej 2012.

[7] Sawczuk W., Tomaszewski F.: Assessing the wear of friction pads in disc braking system of rail vehicle by using selected amplitude characteristics of vibration signal, Vibration In Physical Systems, Volume XXIV s. 355-361.

[8] Ścieszka S.F., Hamulce cierne. Zagadnienia materiałowe, konstrukcyjne i tribologiczne, Wydawnictwo Gliwice-Radom 1998, s.15.

[9] Triches, N.Y. Gerges Samir, R. Jordan, Analysis of brake squeal noise using the finite element method: a parametric study, Applied Acoustics 69 (2008) 147-162 